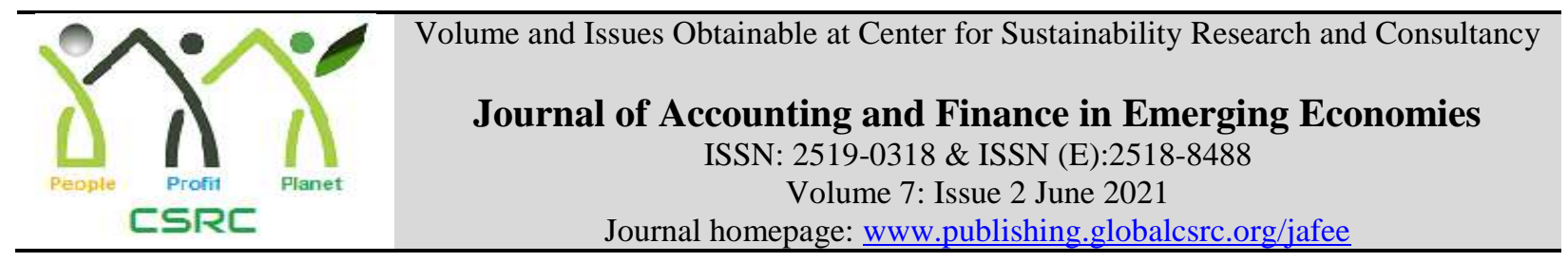

\title{
Revisiting the Dynamic Impact of Fiscal Policy on Inflation in Pakistan
}

Farrah Yasmin, Department of Economics, Govt. Emerson University Multan, Pakistan

Saima Urooge, Department of Economics, Islamia College Peshawar, Pakistan

Muhammad Umair, Department of Economics, Emerson University Multan, Pakistan

*Sher Ali, Department of Economics, Islamia College Peshawar, Pakistan

*Corresponding author's email address: drali@icp.edu.pk

\begin{tabular}{l} 
ARTICLE DETAILS \\
\hline History \\
Revised format: May 2021 \\
Available Online: Jun 2021
\end{tabular}

Keywords

Inflation, Fiscal Policy

Variables, ARDL, Pakistan

JEL Classification

E30, E31, E42, H60, C32

\begin{abstract}
Purpose: The target of the present research study is to examine the Non-Ricardian regime and determination of inflation in an open economy taking the case of Pakistan. Design/Methodology/Approach: This research is carried out for the economy of Pakistan for the period of 1976-2019. To deal with the time series data we need to test the Stationarity of the data in advance to confirm the non-existence of the second I(2) of stationarity. For the purpose of stationarity testing this study used test Phillips Peron (PP) test. PP test results suggested the use of ARDL. Findings: The results of ARDL reported that the intervention of the government has a very important and dominant role the determination of price level (Inflation) in an open economy.
\end{abstract} Implications/Originality/Value: The study has concluded that the government should focus on fiscal measure as well with the extensive use of monetary policy in coordination with fiscal policy to keep inflation in control in Pakistan.

(C) 2021 The authors, under a Creative Commons Attribution-

Recommended citation: Yasmin, F., Urooge, S., Umair, M. and Ali, S. (2021 Revisiting the Dynamic Impact of Fiscal Policy on Inflation in Pakistan. Journal of Accounting and Finance in Emerging Economies, 7 (2), 349-356

\section{Introduction}

Inflation for any economy is not acceptable. It creates very serious problems in the economy for people. In classical view, Ricardian regime and Non-Ricardian regime are used to determine the price level in the economy. Ricardian regime supports monetary policy while Non-Ricardian approach supports fiscal policy as an important instrument in determining price level. Leeper (1991), Sims (1994, 1997), Woodford (1994-95, and 2001), and Cochrane (1998, 2000) supported fiscal determinants of price level. All these studies emphasized importance of fiscal policy performs as a crucial function in determination of the prices in economy. Similarly Sargent and Wallace (1975), Leeper (1991), Micheal Woodford (1994, 1995 and 2001)) favored fiscal theory of price determination in an open economy. While in case of Pakistan, Javid et al. (2008), Moreira et al. (2007), Khan and Agha (2006) etc. also support the fiscal policy to determine the inflation rate. In the procession of above experience, the major inspiration of this study is to 
evaluate that whether the Non-Ricardian regime of fiscal policy has an impact on the volatility of price level in Pakistan in an open economy perspective.

The scheme of study is as follows: section II of the paper provides a brief review of the literature. Data sources and variables description is given in the section III. In section IV, Methodological issues, model specification, estimation and results are discussed and finally section $\mathrm{V}$ presents the concluding remarks and policy recommendation. Lot of studies relevant to the Non-Ricardian regime of fiscal policy and inflation at national and international level are available in the literature. But very few addresses different conclusions related to the Non-Ricardian regime and inflation rate.

Minford and Fan (2011) adopt the fiscal strategy of inflation. They imply FTPL model, cointegration analysis and use indirect inference method for the dynamics of inflation by using time series inflation behavior for the period 1970-IV-1978-IV. They concluded that fiscal policy behaves as exogenously and money growth as endogenously. Moreira et al. (2007) formulate the transmission channels of monetary and fiscal policies in case of Brazil by using quarterly data from 1995 to 2006 and use fiscal IS curve, Philips curve and Leeper Model. They conclude that the Non-Ricardian model is sufficient in case of Brazil because fiscal policy dominance affect output gap directly while it indirectly affect inflation rate. Afonso (2002) discuss the fiscal thought of inflation according to Leeper-Sims-Woodford (LSW). They apply fiscal theory of price level (FTPL) by using panel data; consist of 32 years of observation (1970-2001) for debt to GDP ratio and primary budget surplus in percentage of GDP for the in case of the EU-15 in time period 1970-2001. The results showed that FTPL is not good fit for EU-15 during this time period. Javid et al. (2008) investigate the interface among fiscal surpluses, debt accumulation and price dynamics. They use Vector Autoregressive Model (VAR) model and use time series data from 1971-2007. The study revealed that in case of Pakistan, inflation increased with the change in wealth that affects the nominal public debt whereas the positive result of high inflation is decrease in discount rate. Khan and Agha (2006) formulate the long-standing relationship among fiscal indicators and high prices in case of Pakistan. They analyze time series annual data from 1973 to 2003, and for econometric technique, they developed Vector Error Correction Mechanism, Johansen co-integration technique, and VAR model. The study analyzed that inflation is also associated with money growth and development in monetary stance of an economy. Malik et al. (2006) develop the relationship among economic growth of the country and fiscal devolution of Pakistan with the use of time series data from 1976 to 2019. It is accomplished that if the shares of expenditures of provincial government and government revenues get higher constantly can slow down the velocity of growth in the economy.

\section{Methodology}

\section{Theoretical Background and Model Specification}

Structural problems in developing countries become a big hurdle in controlling inflation through only money supply as suggested by monetarists. Similarly central banks in developing countries are not fully autonomous and changes in money supply depict fiscal actions of the govt. A lot of studies concluded that fiscal action of the govt affect money supply which results in increase in inflation. Akhtar (1975) has tested fiscal policy and foreign trade variables separately in structuralist model to show that changes in fiscal policy are significantly important to determine inflation. In developing countries budget deficit lead to higher prices by creating excess demand for goods and services. Side by side development and non-developing expenditures leads higher inflation. Similarly increasing Govt. debt also contributes to inflation.

Keeping in view the objectives of this research, this study develops a simple model by following Javid et al. (2008) to check the systematic relationship of inflation with number of fiscal explanatory variables. Contrary to Javid et al. (2008) we are using some additional variables in 
our model in case of Pakistan. Therefore the equation of the Fiscal model is as under:

$$
C P I_{t}=\alpha_{1 t}+\alpha_{2 t} R G D P_{t}+\alpha_{3 t} I N V_{t}+\alpha_{4 t} G R E V_{t}+\alpha_{5 t} B D_{t}+\alpha_{6 t} G E X P_{t}+\alpha_{8 t} B O T_{t}+\alpha_{8 t} E R_{t}+\varepsilon
$$

Where CPI is used as a proxy for inflation with base year 2000, following Javid et al. (2008), Minford and Fan (2011), Agha and Khan (2006), Creel and Sterdyniak (2002), and Faridi (2011) who also adopted CPI as a proxy for inflation. Total investment (sum of domestic as well as foreign investment) is also taken as percentage of GDP. It was observed that there is a positive linkage among the inflation and investment. Following Faridi (2011), Sims (1997), Afonso (2002), Sangsubhan and Basri (2012), Javid et al. (2008) and Agha and Khan (2006), the present study is also using real GDP growth rate. If government expenditures (GEXP) and government revenues (GREV) as percentage GDP increases, inflation will also be increased. Different studies also use it as an explanatory variable like Sims (1997), Afonso (2002). Budget Deficit (BD) as Percentage of GDP is used as an explanatory variable on the evidence provided by Sangsubhan and Basri (2012), Moreira et al. (2007), and Afonso (2002). The previous studies have shown that if the balance of trade (BOT) increases there will be fall in Price level. Literature showed that there is a strong bond between ER and inflation rate. As the exchange rate becomes high then it has a negative impact on the rate of inflation because it leads to increase in the import prices that will lead to increase in overall prices of goods and services in the country. Ali et al (2020) also used roundabout the same model in their study to investigate the impact of globalization on inflation in south Asian countries.

\section{Data Sources}

Data are collected for the variables mentioned in the model of the study are taken from Govt. of Pakistan (GOP) economic survey (Various Issues), Statistical Supplement, World Development Indicator (WDI) website.

\section{Econometric Techniques}

It is essential to confirm the stationarity of time series data. For this purpose we use unit root test that helps us to check whether the data is stationary or not. From several available unit root tests, this study is using Phillips Perron (PP) (1988) test to check the stationarity. ADF test assumed that error terms are uncorrelated and have constant variance. Philips and Perron (1998) followed ADF test procedure and allowed for mild assumption about error term distribution. According to Austerio (2006) test regression for PP test is $\mathrm{AR}(1)$ process is as under:

$$
\Delta Y_{t-1}=\propto_{0}+\gamma Y_{t-1}+\varepsilon_{t}
$$

The advantage of PP test over ADF test is that it instead of adding lagged differenced terms on

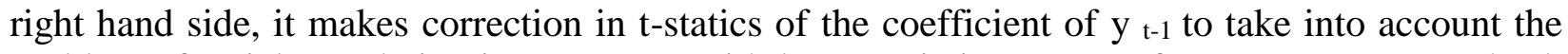
problem of serial correlation in error term with less restrictive nature of error process. We check the stationarity of our data by applying PP test of unit root at 1\%,5\% and 10\% level of significance.

\section{Autoregressive Distributed Lag (ARDL) Model}

For econometric analysis, this study adopts Autoregressive Distributed Lag (ARDL) model. This ADRL approach was developed by Pesaran (1997), Pesaran et al. (2001) and Pesaran and Shin (1995, 1999). According to Pesaran et al. (2001) ARDL approach consists of two steps in estimation of long-run relationship. First step is the investigation of existence of long-run relationship. The second step is investigation of short-run bi-directional causality among the variables. According to Pesaran et al. (2001) the general form of ECM is as under:

$$
\Delta y_{t}=\varphi_{0}+\varphi_{1} t+\tau_{y y} y_{t-1}+\tau_{y x . x} x_{t-1}+\sum_{i=1}^{p-1} \omega \Delta z_{t-1}+\delta \Delta x_{t}+u_{t}
$$


Where $\varphi_{0}$ and $\varphi_{1} \neq 0$. The null hypothesis for Wald test are $H_{0} ; \tau_{y y}=0$ and $H_{0} ; \tau_{y x . x}=0$ and alternate hypothesis are; $H_{1} ; \tau_{y y} \neq 0$ and $H_{1} ; \tau_{y x . x} \neq 0$. The null hypothesis of Wald test is no cointegration. This framework is used for long term and short term trends of causations and consistent among variables and in which this study build a distributed lad that express one series leads to the other series. This approach is applicable when our variable of time series data lays under both I (0) and I (1) in the stationary test.

The asymptotic distributions of the F-statistics are non-standard under the null hypothesis of no cointegration relationship between the examined variables, irrespective of whether the variables are purely $\mathrm{I}(0)$ or $\mathrm{I}(1)$, or mutually co-integrated. Two sets of asymptotic critical values are provided by Pesaran and Pesaran (1997). The first set assumes that all variables are I(0) while the second set assumes that all variables are I(1). If the computed F-statistics is greater than the upper bound critical value, and then we reject the null hypothesis of no cointegration and conclude that there exists steady state equilibrium between the variables. If the computed F-statistics is less than the lower bound critical value, then we cannot reject the null of no cointegration. If the computed F-statistics falls within the lower and upper bound critical values, then the result is inconclusive. After the discussion of theoretical model regarding the ARDL technique,

General ARDL equation for Model is given below.

$$
\begin{aligned}
\Delta c p i_{t}=\alpha_{0} & +\sum_{i=1}^{n} \alpha_{1 t} \Delta(r g d p)_{t-1}+\sum_{i=1}^{n} \alpha_{2 t} \Delta(\text { inv })_{t-1}+\sum_{i=1}^{n} \alpha_{3 t} \Delta(\text { grev })_{t-1} \\
& +\sum_{i=1}^{n} \alpha_{4 t} \Delta(b d)_{t-1}+\sum_{i-1}^{n} \alpha_{5 t} \Delta(\text { gexp })_{t-1}+\sum_{i-1}^{n} \alpha_{6 t} \Delta(\text { bot })_{t-1} \\
& +\sum_{i=1}^{n} \alpha_{7 t} \Delta(\text { er })_{t-1}+\gamma_{1}(r g d p)_{t-1}+\gamma_{2}(\text { inv })_{t-1}+\gamma_{3}(\text { grev })_{t-1} \\
& +\gamma_{4}(b d)_{t-1}+\gamma_{5}(\text { gexp })_{t-1}+\gamma_{6}(\text { bot })_{t-1}+\gamma_{7}(\text { er })_{t-1}+\varepsilon_{t}
\end{aligned}
$$

Here $\Delta$ is the first difference operator. $\alpha_{0}=$ Intercept term while $\alpha_{1}, \alpha_{2}, \alpha_{3}, \ldots . ., \alpha_{8}=$ short term coefficient of the variables of model and $\gamma_{1}, \gamma_{2}, \gamma_{3}, \gamma_{4}, \gamma_{5}, \gamma_{6}, \gamma_{7}$ long run coefficient $\varepsilon \mathrm{t}=$ error term that incorporate those variables that are ignored in the equation. Above equation can be seen as ARDL model of order $\left[\kappa_{1}, \kappa_{2}, \kappa_{3}, \kappa_{4}, \kappa_{5}, \kappa_{6}, \kappa_{7}, \kappa_{8}\right]$.

\section{Results and Discussions}

\section{Unit Root Test (Phillips Perron)}

The results of PP test confirmed that the variables CPI, RGDP, GREV are stationarity at level at $1 \%$ level of significance and the rest of the variables i.e. INV, BD, TAX, GEXP, BOT and ER are became stationary after first difference. PP test concluded that CPI, RGDPG, GREV are stationary at level i.e. I(0) and variables INV, BD, TAX, GEXP, BOT and ER stationary after first difference i.e. $\mathrm{I}(1)^{1}$.

Note: 1\%, 5\% and 10\% critical values for Phillips Perron (PP) level are 3.639, 2.951 and 2.614 for without trend. $1 \%, 5 \%$ and $10 \%$ critical values for with trend are 4.252, 3.548 and 3.207. While $1 \%, 5 \%$ and $10 \%$ critical values for Phillips Perron (PP) for $1^{\text {st }}$ Difference are 3.646, 2.954 and 2.615 for without trend. $1 \%, 5 \%$ and $10 \%$ critical values for with trend are 4.262, 3.552 and 3.209 
Table-1 Bound/Wald Test Results

\begin{tabular}{|l|l|l|}
\hline Estimated Equation & $\begin{array}{l}\text { Ef(RGDP, INV, GREV, BD, GEXP, } \\
\text { BOT, ER) }\end{array}$ \\
\hline F-statistics & $\mathbf{7 . 2 6 0 8}$ \\
\hline Optimum lag order & $\mathbf{( 1 , 1 , 1 , 0 , 1 )}$ \\
\hline Significance Level & $\begin{array}{l}\text { Lower } \\
\text { Bounds }\end{array}$ & Upper Bounds \\
\hline $\mathbf{1}$ per cent & 3.798 & 5.198 \\
\hline $\mathbf{5}$ per cent & 3.047 & 4.906 \\
\hline $\mathbf{1 0}$ per cent & 2.702 & 3.918 \\
\hline
\end{tabular}

The results in Table-1 show that there is Long Run relationship existed among the variables of the model; as the calculated value of F-Statistic is greater than the Upper Bound Critical value i.e. F-Stat > Upper Bound Critical valve (7.2608 > 5.198) at $1 \%$ level of significance.

Table-2: Long Run Results, Dependent Variable CPI

\begin{tabular}{|l|l|l|l|}
\hline Variables & $\begin{array}{l}\text { Co- } \\
\text { 4fficients }\end{array}$ & $\begin{array}{l}\text { T- } \\
\text { Values }\end{array}$ & $\begin{array}{l}\text { P- } \\
\text { Values }\end{array}$ \\
\hline RGDP & -0.42 & -1.91 & 0.070 \\
\hline INV & 0.32 & 1.55 & 0.325 \\
\hline GREV & 1.18 & 3.80 & 0.000 \\
\hline BD & -0.03 & -0.14 & 0.880 \\
\hline GEXP & 1.35 & 3.76 & 0.000 \\
\hline BOT & -0.00 & -2.89 & 0.013 \\
\hline ER & 0.08 & 0.44 & 0.660 \\
\hline C & 2.01 & -0.79 & 0.040 \\
\hline
\end{tabular}

The results of the long run in Table-2 tell us that there in negative impact of real growth on inflation rate in Pakistan. The coefficient RGDP is negative with value -0.42 with their corresponding $\mathrm{T}$-value of -1.91 and Prob-value of 0.070 , means that the variable significant at $10 \%$ level of significance. The results reported that an increase in real GDP growth leads to reduce inflation rate in the country. The impact of Investment and exchange rate are positive but insignificant. Govt. Revenue and Govt. Expenditure have affect price level positively and significantly, mean an increase in Govt. expenditure and Revenue collection leads to increase price level in Pakistan. Moreover, the impact of Balance of trade is negative and significant at 5\% level of significance. It means that an increase in trade balance leads to decrease in inflation rate.

Table-3: Short Run Results

\begin{tabular}{|l|l|l|l|}
\hline \multicolumn{4}{|l}{ Dependent Variables CPI } \\
\hline Variable & Coefficient & T-Value & P-Value \\
\hline C & & & \\
\hline DRGD & -0.37 & -1.95 & 0.07 \\
\hline DINV & 0.20 & 0.30 & 0.76 \\
\hline DGREV & 0.31 & 0.28 & 0.78 \\
\hline DBD & -0.54 & -2.07 & 0.05 \\
\hline DGREV & 1.26 & 0.39 & 0.70 \\
\hline DBOT & 0.67 & 0.11 & 0.91 \\
\hline DER & -0.41 & -1.95 & 0.17 \\
\hline R-Square $=\mathbf{0 . 9 1}$ & & $\begin{array}{l}\text { Prob } \\
\text { 0.000 }\end{array}$ \\
\hline Adj R-Square $=\mathbf{0 . 8 6}$ & DW statistic $)=1.91$ \\
\hline F-statistic $=\mathbf{3 3 . 2 4}$ & & \multicolumn{2}{l}{} \\
\hline
\end{tabular}


The results in Table- 3 reported that the value of $\mathrm{R}^{2}$ is 0.91 ; it means that $91 \%$ percent that the variation in the dependent variable is defined the explanatory variables. And in order to check the serial correlation, this study applied Breusch-Godfrey LM test. According to results, there is no autocorrelation in our model so this study rejects null hypothesis $\left(\mathrm{H}_{\mathrm{o}}\right)$ and accepts alternative hypothesis (H1) that is there is no serial correlation among our variables. So the table 03 shows the significant results of our model for this study.

According to the Table-3, only two variables are statistically significant in the short run. These variables are GREV and BD. Bothe the variables negatively affect inflation in the short run. Means and increase in GREV and BD lead to decrease inflation. So the non-Ricardian regime of fiscal theory influences the price level in an economy than the Ricardian theory of monetary policy.

\section{Conclusion And Policy Recommendation}

This study analyzed the impact fiscal policy or the role of Government in the determination of inflation, a Non-Ricardian regime in open economy through empirical evidence in case of Pakistan. This study dealt with time series data and needed to treat with the stationarity testing. For the stationarity testing PP test is employed. Unit root test suggested that ARDL is suitable technique for estimation. This study claimed that Fiscal policy variables are also important to affect inflation rate in any economy. Because in Pakistan monetary policy remain under pressure due to budget deficit, political instability and other economic crises, therefore, fiscal policy has the potential to affect price level dominantly along with monetary policy. Inflation is measured by CPI and fiscal policy is represented by a combination of GREV and GEXP. Some other important variables are also added to the model based on their importance in the determination of inflation in literature. These variables are RGDP growth, INV, BD and BOT. Results reported that the impacts of fiscal policy variables are positive and significant in the long run, while their positive but insignificant in the short run. The increase in government revenues, domestic investment and consumption expenditure on development for the country will lead to Aggregate demand and result to inflation. Pakistan is a developing country and its monetary policy remains under pressure of budget deficit and political pressure. So the central government may influence the inflation rate in long term dynamics as well as in short term dynamics. Therefore, the NonRicardian view about inflation is valid in the present study and it is suggested that Fiscal Policy could be used in policy formulation to control the level of inflation in case of Pakistan.

\section{Reference}

Afonso, A. (2002). Distributing the fiscal theory of price level: Can it fit the EU-15? Research Institute of Applied Economics .

Agha, A. I., \& Khan, M. S. (2006). An Empirical Analysis of Fiscal Imbalances and Inflation in Pakistan. SBP Research Bulletin , 343-362.

Ali, S. Ali, A \& Khan, S., (2019). Impact of Globalization on Inflation in Selected South Asian Countries: Using Panel Data Techniques. Global Social Sciences Review IV(II), 339 351.

Asteriou, D., \& Hall, S. G. (2011). Applied Econometrics (2nd ed.). Palgrave Macmillan.

Bildirici, M., \& Ersin, Ö. Ö. (2011). Fiscal Theory of Price Level and Economic Crises: The Case of Turkey. Journal of Economic and Social Research , 81-114.

Carlstrom, C. and Fuerst, T.(2000). "The fiscal theory of the price level," Federal Reserve Bank of Cleveland. Economic Review, 1st trimester, 22-32.

Chaudhry, I. S., Akhtar, M. H., Mahmood, K., \& Faridi, M. Z. (2011). Foreign Exchange Reserves and Inflation in Pakistan: Evidence from ARDL Modelling Approach. International Journal of Economics and Finance, 3.

Chena, Y. T., \& Kuanb, C. M. (2005). A Generalized Jarque-Bera Test of Conditional Normality. Institute for Social Sciences and Philosophy . 
Christiano, L. J., \& Fitzgerald, T. J. (April 2000). Understanding the Fiscal Theory of Price Level.

Cochrane, J. (1999). “A Frictionless View of U.S. Inflation,” in Bernanke, B. and Rotemberg, J. (eds.), NBER Macroeconomics Annual 1998, 323-384. 41

Cochrane, J. (2000). "Money as Stock: Price Level Determination with no Money Demand," NBER Working Paper 7498, January.

Cochrane, J. (2001). "Long-term Debt and Optimal Policy in the Fiscal Theory of the Price Level," Econometrica, 69 (1), 69-116.

Creel, J., \& Sterdyniak, H. (2002). The fiscal theory of the price level and sluggish inflation:how important shall the wealth effect be? Observatoire Français des Conjonctures Economiques.

DeBenedictis, L. F., \& Giles, D. E. (1998, October). Diagnostic Testing in Econometrics: Variable Addition, RESET, and Fourier Approximations. A. Ullah \& D.E.A. Giles (eds.), Handbook of Applied Economic Statistics , pp. 383-417.

DeBenedictis, L. F., \& Giles, D. E. (1996, October ). Diagnostic Testing in Econometrics:Variable Addition, RESET, and Fourier Approximations. 383-417.

Economic Survey Report, Government of Pakistan, Ministry of Finance. www.finance.gov.pk/survey_1112.html

Fan, J., \& Minford, P. (2011). Can the Fiscal Theory of the Price Level explain UK Inflation in the 1970s?

Faridi, M. Z. (2011). Contribution of Fiscal Decentralization to Economic Growth: Evidence from Pakistan. Pakistan Journal of Social Sciences (PJSS) , 1-13 .

Fiorentini, G., Sentana, E., \& Calzolari, G. (2003). On the validity of the jarque-bera normality test in conditionally heteroskedastic dynamic regression models. Munich Personal RePEc Archive .

Friedman, Benjamin M (1988), "Lessons on Monetary Policy from the 1980's," Journal of Economic Prospectives 2, pp. 51-72. [http://ideas.repec.org/a/aea/jecper/v2y1988i3p5172.html] (19.09.2007).

Friedman, M., \& Schwartz, A. J. (1965). A Monetary History of the United States, 1867-1960. The Economic Journal .

Handbook of Statistics on Pakistan (2005), State Bank of Pakistan. www.sbp.org.pk

Javid, A. Y., Arif, U., \& Sattar, A. (2008). Testing the Fiscal Theory of Price Level . The Pakistan Development Review , 763-778.

Johansen, S. (1988). Statistical Analysis of cointegration vectors. Journal of Economic Dynamics control, 231-254.

Leeper, E. (1991). "Equilibria under 'Active' and 'Passive' Monetary and FiscalPolicies," Journal of Monetary Economics, 27 (1), 129-147.

Malik, S., hassan, M. u., \& Hussain, S. (2006). Fiscal decentralization and economic growth in Pakistan. The Pakistan Development Review .

Moreira, T. B., Souza, G. d., \& Almeida, C. L. (2007). The Fiscal Theory of the Price Level and the Interaction of Monetary and Fiscal Policies: The Brazilian Case. Brazilian Review of Econometrics , 85-106.

Pesaran, M. H., \& Shin, Y. (1997). An Autoregressive Distributed Lag Modelling Approach to Cointegration Analysis. The Norwegian Academy of Science and Letters .

Pesaran, M. and Smith, R. (1995). "Estimating Long-Run Relationships from Dynamic Heterogeneous Panels," Journal of Econometrics, 68 (1), 79-113.

Renani, H. S. (2007). Demand for money in Iran: An ARDL approach. Munich Personal RePEc Archive .

Sangsubhan, K., \& Basri, M. C. (2012). Global Financial Crisis and ASEAN:Fiscal Policy Response in the Case of Thailand and Indonesia. Asian Economic Policy Review , 248-269.

Sargent, T. and Wallace, N. (1975). "'Rational' expectations, the optimal monetary instrument and the optimal money supply rule", Journal of Political Economy, 83 (2), 241-254. 
Sims, C. (1999). "The Precarious Fiscal Foundations of EMU," De Nederlandsche Bank Staff Reports 34.

Sims, C. (2001). "Fiscal Consequences for Mexico of Adopting the Dollar," Journal of Maoney, Credit, and Banking, 33 (2), parte 2, 617-625.

State Bank of Pakistan (Various Issues) Annual Report. Karachi: State Bank of Pakistan

Woodford, M. (1994). "Monetary Policy and Price Level Determinacy in a Cash-in -Advance Economy," Economic Theory, 4 (3), 345-380.

Woodford, M. (1998a). "Doing without Money: Controlling Inflation in a Post-Monetary World," Review of Economic Dynamics, 1 (1), 173-219.

Woodford, M. (1998b). "Public Debt and the Price Level," mimeo, Princeton University, June.

Woodford, M.(1999). “Comment on Cochrane," in Bernanke, B. and Rotemberg, J. (eds.), NBER Macroeconomics Annual 1998, 390-419.

Woodford, M. (2001)."Fiscal Requirements for Price Stability," Journal of Money, Credit and Banking, 33 (3), 669-728.

Yasmin, F., \& Afzal, M. (November 2012). Modeling Inflation Expectations in Pakistan. International Journal of Research in Social Sciences , Volume 2, 559-566. 